\title{
Investigation on Influence of Ultrasonic Impact Treatment (UIT) on Fatigue Life for Aluminium Alloy 2017-T4
}

\author{
Hussain J. M. Alalkawi \\ Aseel A. Alhamdany \\ Marib R. Abdul Hassan \\ Electromechanical Eng. Dep., University of Technology, Baghdad, IRAQ \\ alalkawi2012@yahoo.com \\ aseelbaky@yahoo.com \\ Received: 30-May-2017 \\ Revised: 10 -Sep.-2017 \\ maarib2011@yahoo.com \\ http://doi.org/10.29194/NJES21010141
}

\begin{abstract}
Improving fatigue life is one of the most important issues in mechanical design; an investigation has been conducted on Al 2017-T4. Group of samples have been machined and prepared, some of specimens have been treated using the ultrasonic impact treatment (UIT) with one line peening. The fatigue tests were carried out under constant and variable amplitude $(\mathrm{R}=-1)$ at ambient temperature, in order to find out the fatigue life $\mathrm{S}-\mathrm{N}$ curve and strength after treatment. It has been found significant increasing in strength after it was treated by (UIT). The fatigue strength is improved after treatment up to $4.16 \%$ at $10^{7}$ cycles, enhancement are present with $24 \%$ and $18.78 \%$ for the cumulative fatigue lives low-high and high-low respectively. These results also show a strong tendency of increasing of fatigue strength after application of (UIT) with increase in mechanical properties of material used.
\end{abstract}

Keywords: constant fatigue, cumulative fatigue, Aluminium alloy 2017-T4, ultrasonic impact treatment (UIT).

\section{Introduction}

There are many conventional methods to treat surfaces from the tension residual stresses, like grinding, polishing, shot peening and spot shot peening methods, helps to remove residual stresses which are exist in manufacturing processes. A method call ultrasonic impact peening treatment (UIT) has been used to treat surfaces from stress concentration efficiently with less consuming time and cost. UIT method can improve the fatigue life and strength, hardness, corrosion and wear resistance as well [1].

This process able to change the residual tension stress to the compressive residual stress, make the surface cracks less deep, and be able to change the grain boundaries orientation on the surface which can increase fatigue life and strength[2].

UIT has been used with metals like, Aluminium, steel, bronze and iron. Many papers deal with this treatment for steel especially in welled joint, it has found improving in fatigue life and strength because of two important factors the first one is compressive residual stress and the second one is change of crack orientation. These effects are increase as the crack became shorter. [3-9].

Aluminium alloy 2017-T4 has been used widely in many applications transportation, construction and industrial, improving fatigue life for this alloy using new method promising to improve the strength of this alloy especially when it has been used in some Al alloy. Investigation has been down on the application of the ultrasonic impact treatment on spokes of cast $\mathrm{Al}$ (AlSi11Mg) wheel and its influence under loading [10]. It has found improving in mechanical porosity and hardness. The method ultrasonic impact treatment makes a compressive residual stresses at the surface. Both treated and untreated spokes under constant and variable fatigue loading were tested, the fatigue strength increased significantly compared to the untreated spokes under constant and variable amplitude bending loading. The UIT-technology promises for improving of the structural strength and saving of metal in the production of cast $\mathrm{Al}$ wheels.

(UIT) have been used on 7075-T6511 alloys which were naturally exfoliated. The Al alloy specimens were fabricated from C-141 aircraft upper wing skin panels. Tests were carried out on specimens using UIT and then fatigue tests for both treated and untreated specimens. Scanning electron microscopy (SEM), analyses were carried out on the fatigue specimens to find the crack nucleating.

The results suggested that the method of ultrasonic impact treatment had a large effect to extend the fatigue lives of the naturally exfoliated 7075-T6511. It was found the UIT changed the crack nucleating mechanism, which then resulted in a much longer fatigue life [11]. For the severely corrosion specimen, the UIT improved the fatigue life a little, the crack still nucleated from intergranular cracking, which could not be removed by the UIT method.

The aim of this study is improving the fatigue life for Aluminium 2017-T4 after treated by an ultrasonic impact treatment (UIT) which raised mechanical properties resulting in improving the fatigue performance. 


\section{Experimental work}

The metal used for the present work is 2017$\mathrm{T} 4 \mathrm{Al}$ alloy. Table (1) gives the chemical composition in wt\%.

Table 1: chemical composition of 2017-T4 Al alloy examined at state company for standard and measured in wt. \%.

\begin{tabular}{|c|c|c|c|c|c|c|c|c|c|c|}
\hline $\begin{array}{c}\text { Elements } \\
\text { wt.\% }\end{array}$ & $\mathrm{Cr}$ & $\mathrm{Zn}$ & $\mathrm{Cu}$ & $\mathrm{Si}$ & $\mathrm{Ti}$ & $\mathrm{Mn}$ & $\mathrm{Mg}$ & $\mathrm{Fe}$ & \begin{tabular}{|c|} 
othe \\
rs
\end{tabular} & $\mathrm{Al}$ \\
\hline $\begin{array}{c}\text { Standard } \\
\text { [12] }\end{array}$ & 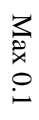 & 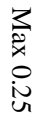 & $\begin{array}{l}\omega \\
\dot{c} \\
1 \\
\dot{c} \\
\dot{c}\end{array}$ & $\begin{array}{l}0 \\
\dot{1} \\
\vdots \\
\infty\end{array}$ & 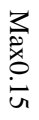 & $\begin{array}{l}0 \\
\dot{1} \\
i \\
1\end{array}$ & $\begin{array}{l}0 \\
\dot{1} \\
1 \\
0 \\
\infty\end{array}$ & 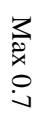 & $\stackrel{\circ}{\dot{\varphi}}$ & 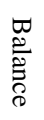 \\
\hline Experimental & $\stackrel{\circ}{i}$ & $\stackrel{0}{v}$ & $\begin{array}{l}\omega \\
\infty \\
\omega \\
\omega\end{array}$ & 吕 & $\stackrel{\circ}{\circ}$ & $\begin{array}{l}0 \\
9 \\
9\end{array}$ & $\stackrel{\circ}{N}$ & 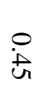 & i & 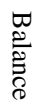 \\
\hline
\end{tabular}

The mechanical properties of 2017-T4 Al alloy are compared with Ref [12] are summarized in table (2).

Table 2: mechanical properties of 2017-T4 Al alloy tested compared with the standard

\begin{tabular}{|c|c|c|c|c|}
\hline $\begin{array}{l}\text { 2017-T4 Al } \\
\text { alloy } \\
\text { properties }\end{array}$ & $\begin{array}{c}\text { Hardness } \\
\text { HB }\end{array}$ & $\begin{array}{c}\text { Strength } \\
\sigma \mathrm{u} \\
(\mathrm{MPa})\end{array}$ & $\begin{array}{c}\text { Yield } \\
\text { stress } \\
\sigma y \\
(\mathrm{MPa})\end{array}$ & $\begin{array}{l}\text { Modules } \\
\text { of } \\
\text { elasticity } \\
(\mathrm{GPa})\end{array}$ \\
\hline Standard & 105 & 427 & 276 & 72.4 \\
\hline Experimental & 112 & 432 & 252 & 78 \\
\hline
\end{tabular}

\subsection{Fatigue testing specimen:}

It has been used programmable CNC lathing machine for machining fatigue specimens. A good surface finish has been done in order to reduce the tensile residual stresses. The surface of all specimens were prepared by grinding with silicon carbide papers (different numbers), then polishing them using three different diamond laps, course $3 / 2$ micron, fine 1 micron and extra-fine 1/4 micron. Finally it was carefully cleaned the specimens, numbered and tested for measuring the roughness of selected specimens as presented in table (3). All the machining processes were carried at the University of Technology, Material Engineering Department.

Table 3: surface roughness results of selected specimens.

\begin{tabular}{|c|c|c|}
\hline $\begin{array}{c}\text { Specimens } \\
\text { No }\end{array}$ & $\begin{array}{c}\text { Surface } \\
\text { roughness (Ra } \\
\mu \mathrm{m})\end{array}$ & $\begin{array}{c}\text { Surface } \\
\text { roughness (Rt } \\
\mu \mathrm{m})\end{array}$ \\
\hline 1 & 0.85 & 1.8 \\
3 & 0.92 & 2 \\
5 & 1.07 & 1.66 \\
7 & 1.2 & 2.1 \\
9 & 1.08 & 2.2 \\
11 & 1.1 & 2.3 \\
13 & 1.2 & 2.08 \\
15 & 0.97 & 1.88 \\
\hline
\end{tabular}

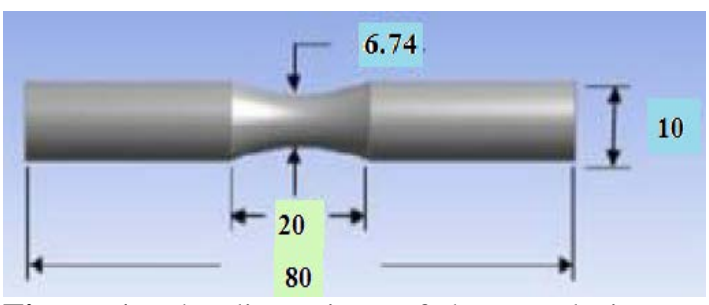

Figure 1: The dimensions of the sample in $\mathrm{mm}$ due to (DIN 50113) standard values [12].

The testing is tension compression stress cycles $(\mathrm{R}=-1)$ with different level of stresses. Test frequency is $23.34 \mathrm{~Hz}$. The fatigue testing was stopped automatically after failure occurred and the number of cycles was recorded. The applied rotating bending stress was calculated using the equation

$$
\sigma_{\text {bending }}(\mathrm{MPa})=\frac{\mathrm{My}}{\mathrm{I}}
$$

Where $\mathrm{M}$ is the bending moment subjected to the minimum diameter of the specimen $(6.4 \mathrm{~mm})$ which is equal to $\mathrm{P} * \mathrm{~L}$ where $\mathrm{P}$ is applied force in Newton and $\mathrm{L}$ is the force arm which is equal to $125.7 \mathrm{~mm}$. I is the second moment of inertia $=\frac{\pi \mathrm{d}^{4}}{64}$ . Equation (1) can be written after substituting I, $\mathrm{y}=\mathrm{d} / 2$ and $\mathrm{M}$ as

$$
\begin{gathered}
\sigma(\mathrm{MPa})=\frac{125.7 \mathrm{P} * \mathrm{~d} / 2}{\frac{\pi \mathrm{d}^{4}}{64}} \ldots \ldots \ldots . .(2) \\
\sigma(\mathrm{MPa})=\frac{1280.37 \mathrm{P}(\mathrm{N})}{\mathrm{d}^{3}\left(\mathrm{~mm}^{3}\right)} \ldots \ldots \ldots \ldots . .
\end{gathered}
$$

Fig. (2) Shows the fatigue test machine.

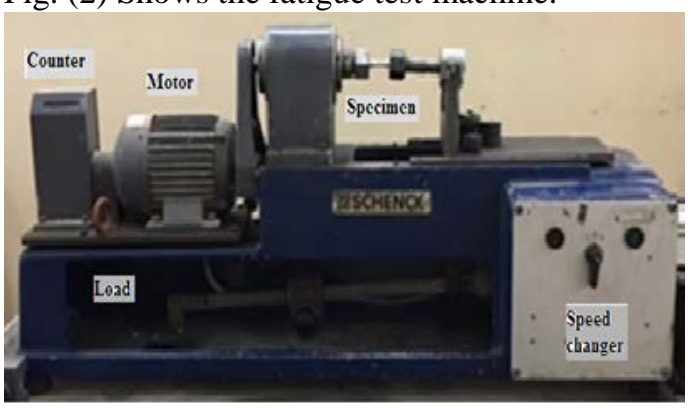

Figure 2: Fatigue test device.

\subsection{Ultrasonic pre stressing force treatment machine:}

Ultrasonic impact treatment (UIT) machine is used for improving the surface properties. The principles is to use of high power ultrasonic drive impact tools more than twenty thousand times per second frequency impact metal surface, due to the high frequency ultrasound, efficient, and focus on the big energy, make the metal surface produces a larger plastic deformation pressure. Ultrasonic wave has changed the original stress field at the same time, have a certain value of compressive 
stress. The time of ultrasonic peening for each specimen was applied for 35 sec (one line). All the fatigue tests were done at the university of Technology Electromechanical Engineering Department.

\section{Main technical parameters}

Applicable materials: Aluminium alloy, low carbon steel, high carbon steel, etc.

Power supply: 220V, 50Hz, 5 A. (AC)

Operation frequency: $20 \mathrm{kHz}$ (output frequency) Maximum power: $500 \mathrm{~W}$ (output power) Adjustable (10\%-100\%)

Size of gun: length $450 \mathrm{~mm}$

Gun weight: $4 \mathrm{~kg}$

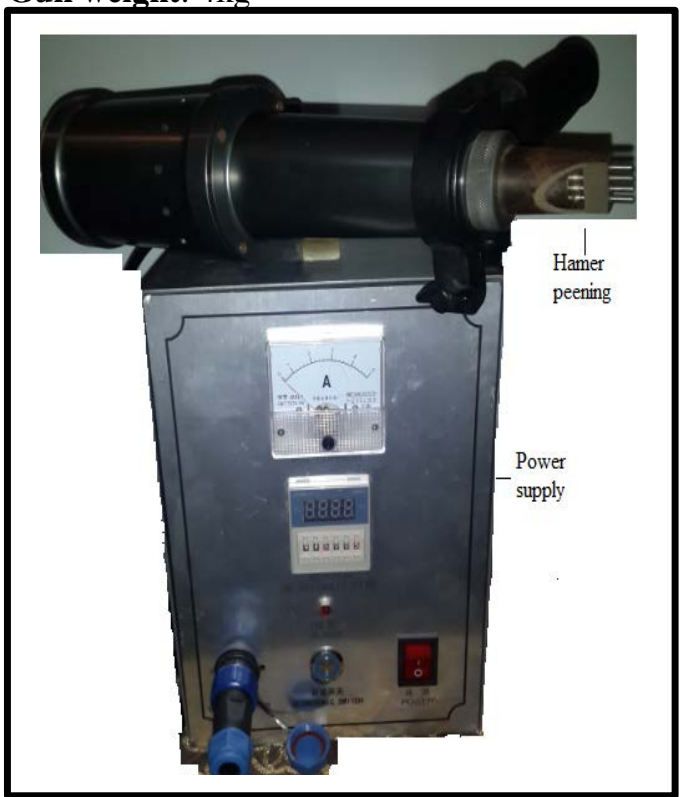

Figure 3: Shows the UIT device.

\section{Results and Discussion}

\subsection{Constant fatigue results}

Two groups of testing were examined under constant fatigue stress of $\mathrm{R}$ (Stress ratio)=-1 and room temperature (RT). The purpose of testing was to establish the S-N curves for both cases, without peening and with one line ultrasonic impact peening treatment (UIT). The results are listed in table (4) and plotted in fig (4).

Fig(4) describes the results obtained from constant stress amplitude tests at room temperature under stress control condition and zero mean stress with and without ultrasonic peening treatment (UIT).

The bending stress was calculated from the bending moment using the relation

$$
\sigma b(\mathrm{MPa})=125.7 * 32 \mathrm{P}(\mathrm{N}) / \pi \mathrm{d}^{3}
$$

Where $\mathrm{P}$ is the applied load $(\mathrm{N})$ and the arm of the force is equal to $125.7 \mathrm{~mm}$ and $\mathrm{d}$ is the minimum diameter of the specimen in $\mathrm{mm}$. It is observed that the fatigue life of (UIT) specimen is improved compared to unpeened specimen.

Table 4: S-N curve results of Al 2017-T4 without and with ultrasonic impact peening.

\begin{tabular}{|c|c|c|c|c|c|c|}
\hline \multicolumn{7}{|c|}{ Al alloy 2017-T4 } \\
\hline \multicolumn{3}{|c|}{$\begin{array}{c}\text { Specimen } \\
\text { No. }\end{array}$} & $\begin{array}{c}\text { Applied } \\
\text { stress(MPa) }\end{array}$ & \multicolumn{3}{|c|}{$N_{f}$ cycles } \\
\hline 1 & 2 & 3 & 300 & 11500 & 16000 & 18000 \\
\hline 4 & 5 & 6 & 270 & 28000 & 32000 & 29600 \\
\hline 7 & 8 & 9 & 210 & 242000 & 210000 & 198000 \\
\hline 10 & 11 & 12 & 180 & 360000 & 330000 & 370000 \\
\hline 13 & 14 & 15 & 150 & $1.28 * 10^{6}$ & $1.41 * 10^{6}$ & $1.09 * 10^{6}$ \\
\hline \multicolumn{7}{|c|}{ Al alloy 2017-T4 Ultrasonic peening } \\
\hline \multicolumn{3}{|c|}{$\begin{array}{c}\text { Specimen } \\
\text { No. }\end{array}$} & $\begin{array}{c}\text { Applied } \\
\text { stress(MPa) }\end{array}$ & \multicolumn{3}{|c|}{$N_{f}$ cycles } \\
\hline 16 & 17 & 18 & 300 & 18000 & 22000 & 26000 \\
\hline 19 & 20 & 21 & 270 & 44000 & 35000 & 37000 \\
\hline 22 & 23 & 24 & 210 & 280000 & 255000 & 301000 \\
\hline 25 & 26 & 27 & 180 & $3.9 * 10^{5}$ & $3.8 * 10^{5}$ & $4.5^{*} 10^{5}$ \\
\hline 28 & 29 & 30 & 150 & $1.6 * 10^{6}$ & $1.9 * 10^{6}$ & $1.6 * 10^{6}$ \\
\hline
\end{tabular}

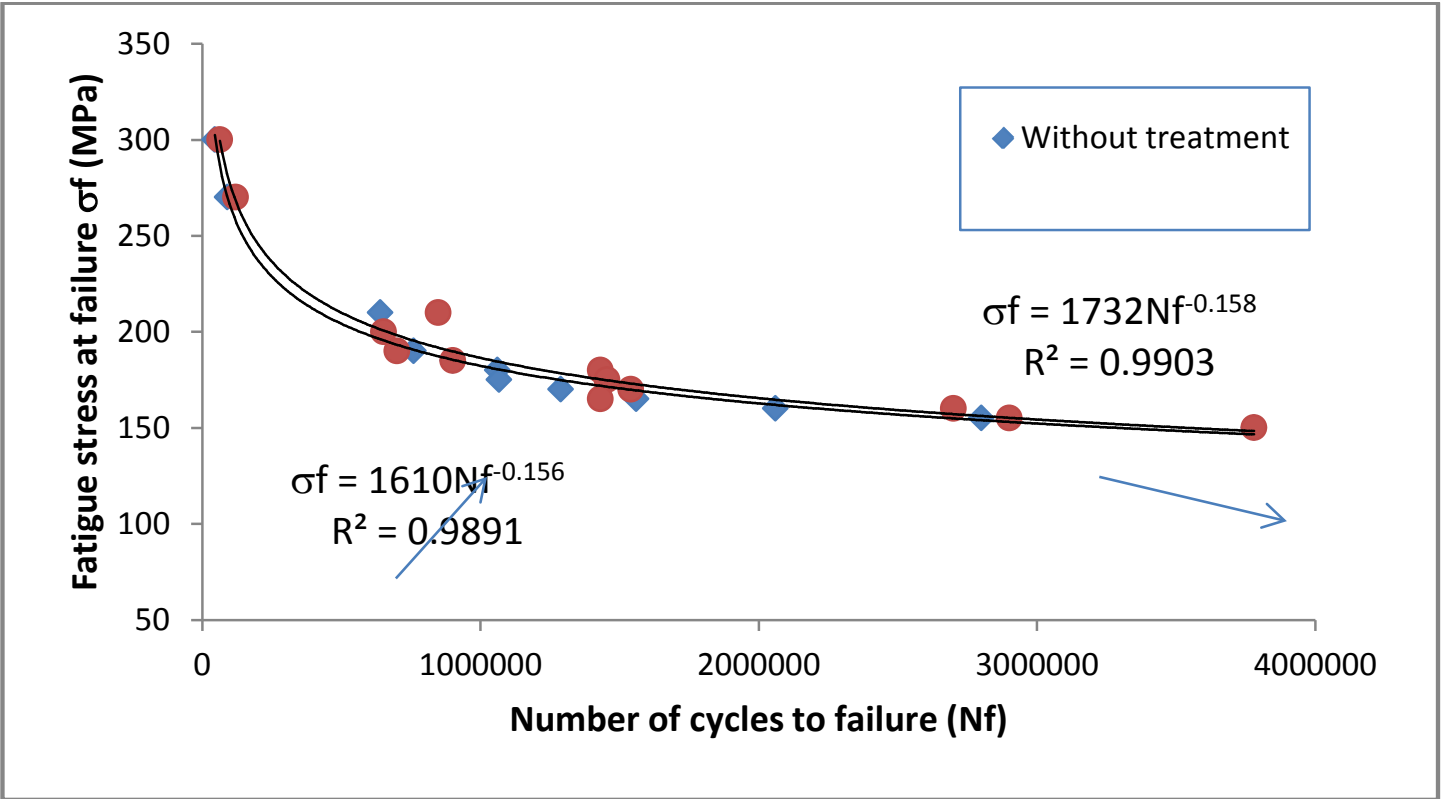

Figure.4: S-N curves for both untreated and treated with ultrasonic peened. 
From table (4), the best fit equation which accurately describes the behaviour of the metal and the Basquin formula which can be written in the form.

$$
\sigma_{\mathrm{f}}=\mathrm{aN}_{\mathrm{f}}^{\mathrm{b}}
$$

Where $\mathrm{a}, \mathrm{b}$ are material constants. These constants can be obtained by the equations

$$
\mathrm{b}=\frac{\mathrm{h} \sum_{\mathrm{i}=1}^{\mathrm{h}} \log \sigma_{\mathrm{fi}} \log N_{\mathrm{fi}}-\sum_{\mathrm{i}=1}^{\mathrm{h}} \log \sigma_{\mathrm{fi}} \sum_{\mathrm{i}=}^{\mathrm{h}} \log N_{\mathrm{fi}}}{\mathrm{h} \sum_{\mathrm{i}=1}^{\mathrm{h}}\left(\log \mathrm{N}_{\mathrm{fi}}\right)^{2}-\left[\sum_{\mathrm{i}=1}^{\mathrm{h}} \log \mathrm{N}_{\mathrm{fi}}\right]^{2}} .
$$

And

$$
\log \mathrm{a}=\frac{\sum_{\mathrm{i}=1}^{\mathrm{h}} \log \sigma_{\mathrm{fi}}-\mathrm{b} \sum_{\mathrm{i}=1}^{\mathrm{h}} \log \mathrm{N}_{\mathrm{fi}}}{\mathrm{h}}
$$

Where $\mathrm{h}$ is the number of test specimens

Table (5) presents the results for both cases without and with treatment, by applying the data in table (4) using the above equations, experimental and the Basquin equations with their correlation coefficients (R2) and the endurance limits of fatigue are shown.

The IF was calculated using the equation

$$
\mathrm{IF}=\frac{\mathrm{N}_{\mathrm{fUIT}}-\mathrm{N}_{\text {fun-peened }}}{\mathrm{N}_{\text {fun-peened }}} * 100
$$

Table 5: Basquin equations with correlation factor for metal and composite.

\begin{tabular}{|c|c|c|}
\hline $\begin{array}{c}\text { 2017-T4 Al } \\
\text { without } \\
\text { treatment }\end{array}$ & $\begin{array}{c}\text { 2017-T4 Al } \\
\text { with (UIT) } \\
\text { method }\end{array}$ & $\begin{array}{c}\text { Improvement } \\
\text { factor (IF) for } \\
\text { fatigue } \\
\text { endurance } \\
\text { limit }\end{array}$ \\
\cline { 1 - 2 } $\begin{array}{c}\sigma_{\mathrm{f}}=1610 \mathrm{~N}_{\mathrm{f}}^{-0.156} \\
\mathrm{R}^{2}=0.9891 \mathrm{MPa}\end{array}$ & $\begin{array}{c}\sigma_{\mathrm{f}} \\
=1732 \mathrm{~N}_{0.9903}^{-0.158} \\
\mathrm{R}^{2}=0.9903\end{array}$ & \multirow{2}{*}{4.16} \\
\cline { 1 - 2 } $\begin{array}{c}\sigma_{\mathrm{EL}}=130 \mathrm{MPa} \text { at } \\
10^{7} \text { cycles }\end{array}$ & $\begin{array}{c}\sigma_{\mathrm{EL}}=136 \mathrm{MPa} \\
\text { at } 10^{7} \text { cycles }\end{array}$ & \\
\cline { 1 - 2 } & \multicolumn{2}{|c}{} \\
\hline
\end{tabular}

\subsection{Cumulative fatigue results:}

Cumulative fatigue tests were carried out at the same conditions for $\mathrm{S}-\mathrm{N}$ curve i-e room temperature (RT) and stress ratio $(\mathrm{R}=-1)$.

Table (6) gives the experimental results obtained for unpeened and ultrasonic peened.

Table 6: cumulative fatigue results for unpeened and ultrasonic peened.

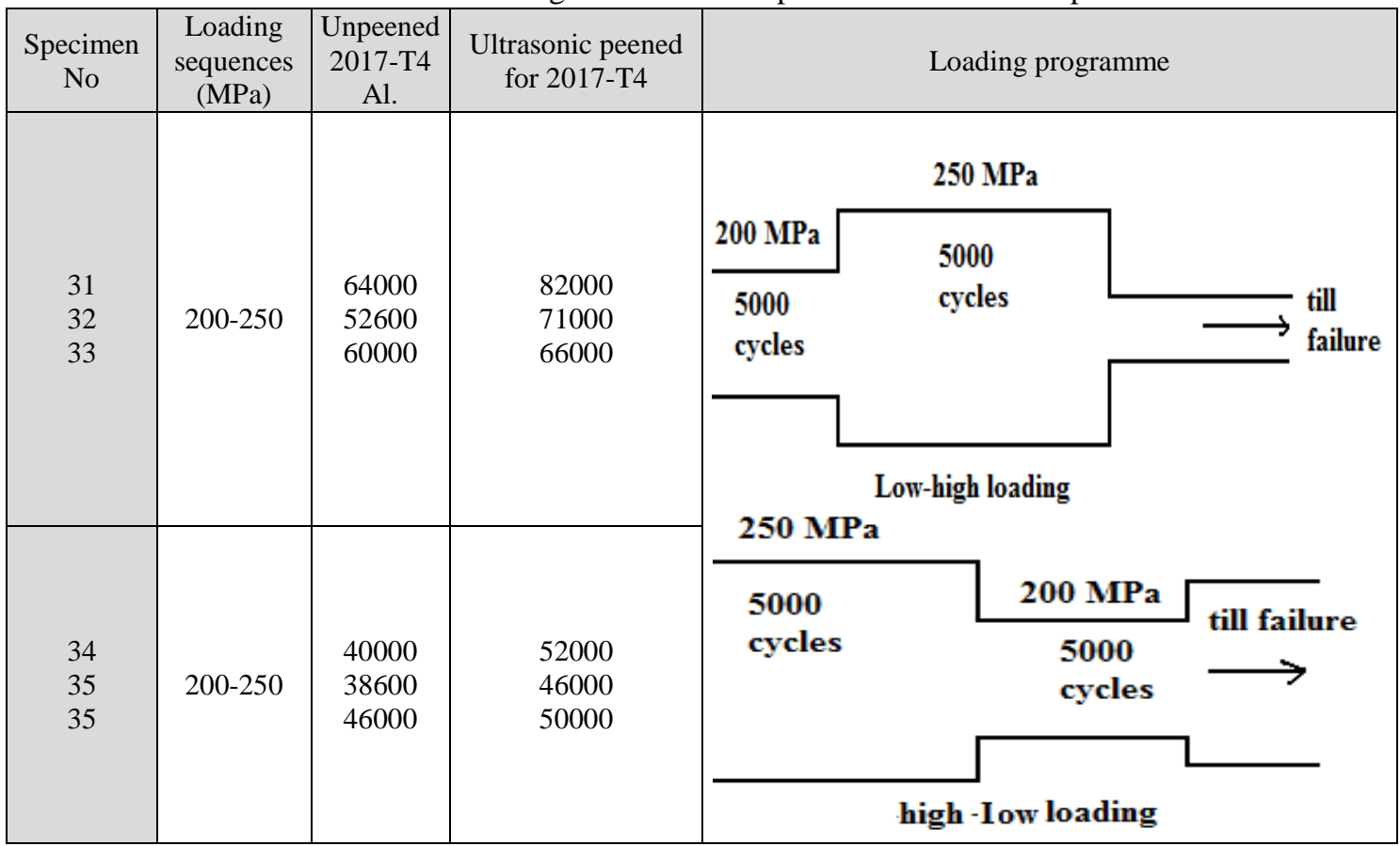

The improvement in cumulative fatigue lives can be seen in table (7).

Table 7: shows the improvement factor (IF) for cumulative fatigue live.

\begin{tabular}{|c|c|c|c|}
\hline $\begin{array}{c}\text { Loading } \\
\text { sequences } \\
\text { (MPa) }\end{array}$ & $\begin{array}{c}\text { Nf average } \\
\text { unpeened }\end{array}$ & $\begin{array}{c}\text { Nf } \\
\text { average } \\
\text { (UIT) }\end{array}$ & IF \\
\hline $200-250$ & 58867 & 73000 & $24 \%$ \\
\hline $250-200$ & 41533 & 49333 & $18.78 \%$ \\
\hline
\end{tabular}

The ultrasonic impact peening (UIT) process generates a number of positive effects in metals and alloys. The main effect is to increase the strength of materials to surface related failures, example fatigue and corrosion. The results of UIT on fatigue testing observed that the above technique is the most efficient for improving the fatigue life and strength of welded parts [13]. The enhancement in fatigue strength and life by(UIT) is achieved mainly by reducing the tensile stresses and increasing the compressive residual stresses at the metal surface. The (UIT) treatment provides good fatigue characteristics in comparison with 
shot peening and hammer peening [14]. For the present results, the endurance fatigue limit is improved by $4.16 \%$ compared to un-peened and the cumulative fatigue lives were enhanced by $24 \%$ and $18.78 \%$ for low-high and high-low loading respectively. This related to the beneficial effect of UIT which is achieved mainly by reliving of tensile residual stress and introducing of compressive residual stresses into the layers of surface of the metal. The other reason is increasing the mechanical properties of specimens treated by (UIT) [15].

\section{Conclusions}

1. The constant fatigue properties are considerably improved by (UIT) technique. The fatigue strength at 107 cycles is improved by $4.16 \%$ due to ultrasonic impact peening specimen surfaces.

2. The (UIT) technique is found as suitable method for hardening the surface of metals.

3. The (UIT) method showed improved the cumulative fatigue properties such fatigue life is enhanced by $24 \%$ and $18.78 \%$ for low-high and high-low in comparison with unpeened specimens.

\section{Acknowledgments}

The authors are grateful to the University of Technology/Department of Electromechanical engineering for the provision of laboratory facilities.

\section{References:}

1. X. Yang, X. Ling , J. Zhou, "Optimization of the fatigue resistance of AISI304 stainless steel by ultrasonic impact treatment", International Journal of Fatigue, 61, 28-38, (2014).

2. A. K. Gujba. M. Medraj," Laser Peening Process and Its Impact on Materials Properties in Comparison with Shot Peening and Ultrasonic Impact Peening", Materials, 7), 7925-7974, (2014).

3. V.M. Lihavainen1, G. Marquis1, E.S. Statnikov2," Fatigue Strength of A Longitudinal Attachment Improved By Ultrasonic Impact Treatment", Welding in the World, 48, no 5/6 , (2004).

4. A. Abdullah, M. Malaki, A. Eskandari, "Strength enhancement of the welded structures by ultrasonic peening", Materials and Design, 38, 7-18, (2012).

5. P. Schaumann, C. Keindorf,"Enhancing fatigue strength by Ultrasonic Impact
Treatment for welded joints of offshore structures", Institute for Steel Construction, Leibniz University, For Wind Centre for Wind energy Research, Hannover, Germany,(2007) .

6. L. Huo, D. Wang, Y. Zhang," Investigation of the fatigue behaviour of the welded joints treated by TIG dressing and ultrasonic peening under variable-amplitude load", International Journal of Fatigue, 27, 95-101, (2005).

7. X. Zhao, M. Wang, Z. Zhang, Y. Liu," The Effect of Ultrasonic Peening Treatment on Fatigue Performance of Welded Joints", Materials , 9, 471-480,(2016)

8. S. Roy , J. W. Fisher, B. T. Yen, "Fatigue resistance of welded details enhanced by ultrasonic impact Treatment (UIT)", International Journal of Fatigue, 25, 12391247, (2003).

9. H. Zhang, D. Wang, L. Xia, Z. Lei, Y. Li, "Effects of ultrasonic impact treatment on prefatigue loaded high-strength steel welded joints", International Journal of Fatigue,80, 278-287, (2015)

10. A. Berg-Pollack, F. J. Vollmecke, C. M. Sonsino, "Fatigue strength improvement by ultrasonic impact treatment of highly stressed spokes of cast aluminium wheels ", International Journal of Fatigue 33, 513-518, (2013).

11. M. Liao, W.R. Chen, N. C. Bellinger," Effect of ultrasonic impact treatment on fatigue behaviour of naturally exfoliated aluminium alloys ", International Journal of Fatigue", 30,717-726, (2008).

12. N. M. Abdulmuhssan, A. H. Hamed and H. J. Al-Alkawi," Effect of Temperature on Fatigue Transition life and Strength of Aluminium alloy", Engineering and Technology Journal, .30, N0.6 , (2012).

13. Y.Kudryavtsev,J.Kleiman,"Increasing fatigue strength of welded elements and structures by ultrasonic impact treatment", International institute of welding (IIW),Document XIII,2318-10,(2010).

14. Y.Kudryavtsev, "Residual stress", Springer handbook on experimental solid mechanics, springer-SEM, 371-387,(2008).

15. H. J. M Alalkawi, A. E. Elkhawad, Y. K. Ali " Analysis of ultrasonic peening mechanical properties and fatigue damage of 2017-T3 aluminium alloy", International J. of Engineering and environment (IJEE),7, No.3 8-14, (2016). 


\section{التحقق من تاتير المعالجة بالموجات فوق الصوتية (UIT) على عمر الكلال لسبيكة}

\section{الالمنيوم 2017-T4}

$$
\begin{aligned}
& \text { مارب رضا عبد الحسن } \\
& \text { قسم هندسة الكهروميكانيك } \\
& \text { الجامعة التكنولوجية }
\end{aligned}
$$

\author{
اسيل عبدالباقي الحمداني \\ قسم هندسة الكهروميكانيك الكياني \\ الجامعة التكنولوجية
}

\author{
حسين جاسم محمد العلكاوي

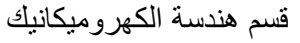

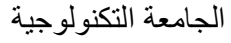

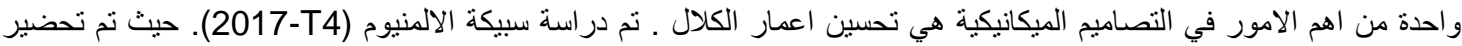

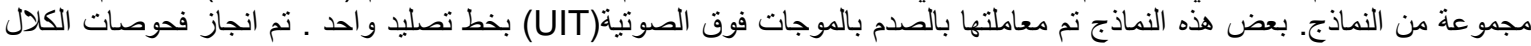

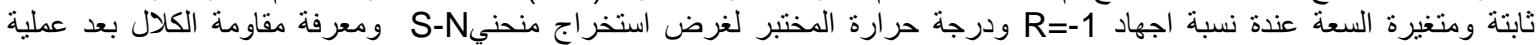

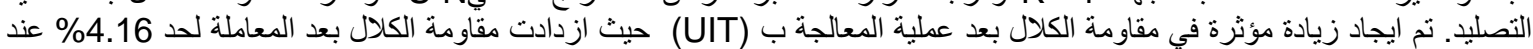

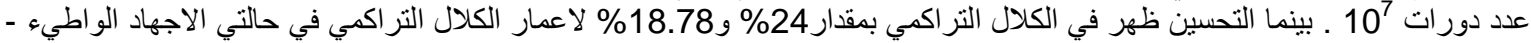

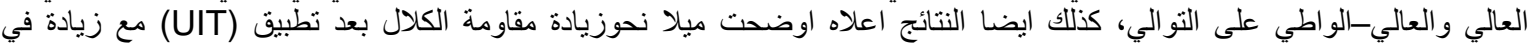
المواصفات الميكانيكية للمادة المستخدمة. الكلمات المرشدة: الكلال ثابت السعة،الكلال التراكمي. سبيكة الالمنيوم 2017-T4 ،المعاملة السطحية بواسطة الصدم بالموجات فوق الصوتية 